\title{
POSSIBILITIES OF SPATIAL DATA TO DETERMINE THE EXTENT OF THE OCCUPANCY OF THE RIGHT-OF-WAY BY LARGE-FORMAT ADVERTISEMENTS
}

\author{
Agnieszka Bieda, PhD \\ AGH University of Science and Technology \\ e-mail:bieda@agh.edu.pl \\ Anita Kwartnik-Pruc, PhD \\ AGH University of Science and Technology \\ e-mail:akwart@agh.edu.pl \\ Edyta Puniach, PhD \\ AGH University of Science and Technology \\ e-mail: epuniach@agh.edu.pl
}

\begin{abstract}
Large-format advertisements are becoming a more and more common element of building facades, especially in city centers. Placing an object of this type is not without significance to the real property management. A large-format advertising billboard on the facade, on the one hand, is associated with the possibility of renting advertising space, on the other - it can lead to the occupancy of a right-ofway, which results in a necessity to pay appropriate fees, in the amount regulated by the Act on Public Roads.

Placing an object such as a large-format advertising billboard in a right-of-way requires a permit of the manager of this road. However, if a billboard is located on the facade of a building, occupancy of the right-of-way is not always the case. If the boundary of the road parcel runs along the contour of the building, a billboard placed on the elevation will always occupy the right-of-way. However, property boundaries often run at a distance from the building. Such situations - desired by managers result in a noticeable increase in demand for surveying opinions to determine what part of the rightof-way is occupied by a large-format advertisement.

This article analyzes the cases of the right-of-way being occupied by large-format advertising placed on the facades of buildings in the city center. For selected objects, information was obtained from public records, National Cartographic Documentation Center database, and direct surveying was performed with various techniques. This allowed for an objective assessment of the possible use of available surveying methods and the acquired spatial data to determine the right-of-way occupied by large-format advertisements for purposes of real estate management.
\end{abstract}

Key words: advertisement, right-of-way, occupancy of the right-of-way, fee for the occupancy of the right-ofway.

JEL Classification: H27, L85, M37, R52.

Citation: Bieda A., Kwartnik-Pruc A., Puniach E., 2017, Possibilities of Spatial Data to Determine the Extent of the Occupancy of the Right-Of-Way by Large-Format Advertisements, Real Estate Management and Valuation, vol. 25, no. 2, pp. 05-19.

DOI: $10.1515 /$ remav-2017-0009 


\section{Introduction}

Large-format advertisements are becoming an increasingly popular element of building facades, especially in city centers. Advertising boards are among the most popular forms of advertising media (Lichtenthal et al., 2006). Placing elements of this type is not without significance to real property management. A large-format advertising billboard on the facade is, on the one hand, associated with the possibility of renting advertising space; on the other - it can lead to the occupancy of a right-ofway, which results in the necessity to pay appropriate fees (PŁUCIENNIK et al., 2015) in the amount regulated by the Act on Public Roads.

Placing an object such as a large-format advertisement in a right-of-way requires a permit of the manager of this road. However, if an advertisement is located on the facade of a building, occupancy of the right-of-way is not always the case. If the boundary of the road parcel runs along the contour of the building, a billboard placed on the elevation will always occupy the right-of-way, as long as its position is determined unambiguously (BIEDA, HANUS, 2010). However, property boundaries often run at a distance from the building. Such situations - desired by managers - result in a noticeable increase in demand for surveying opinions to determine what part of the right-of-way is occupied by a large-format advertisement.

\section{Summary of the legal provisions concerning the placement of advertising in public space}

Below is the legal basis regarding the placement of large-format advertising. The changes which took place last year relate to the basic definitions. Further in this article, the provisions relating to the costs incurred by the occupancy of a right-of-way by advertising have been presented in an orderly manner.

\subsection{Definitions}

As a result of the act on amendments to some laws in connection with the strengthening of the tools of landscape protection (Act, 2015) entering into force on 11 September 2015, some definitions of terms related to advertisements have arisen in the basic normative acts regulating the issues of the management of space around roads. These definitions are essential to determining the possibility of placing a given kind of advertisement in a specific location and determining fees therefrom.

The Act on Spatial Planning and Development (Act, 2003) contains the concept of advertising, understood as "dissemination of information, in any visual form, promoting persons, companies, products, services, projects or social movements" (art. 2 clause 16a). The following were also defined:

- advertising board as "a material object designed or used for advertisement exposure, together with its structural elements and fixings, with a flat surface used for advertisement exposure, particularly an advertising banner, advertisements stuck on windows and advertisements placed on scaffolding, fence or construction site equipment, with the exception of small everyday objects used for their intended purpose (art. 2 clause 16b),

- advertising device as a material object designed or used for advertisement exposure, together with its structural elements and fixings, other than an advertising board, with the exception of small everyday objects used for their intended purpose (art. 2 clause 16c),

- signboard as an advertising board or an advertising device displaying a message pertaining to a business or service conducted or provided on the property on which the device is located (art. 2 clause 16d).

In addition, it was introduced in the Act that the municipal council may determine, by way of a resolution, the terms and conditions of locating advertising boards and advertising devices, their dimensions, quality standards, and types of building materials which they may be made of, but also that the council may ban their placement. The Act deals with signboards in a slightly different way, allowing the municipal council to determine, by way of a resolution, the terms and conditions of their location, dimensions and number in which they can be placed on a given real property by an entrepreneur running a business activity, without the possibility to ban their placement.

The definition of an advertisement also appeared in the Act on Public Roads (Act 1985). Pursuant to article 4 clause 23 , an advertisement is an advertising board or an advertising device within the meaning of Article 2 Clauses 16b and 16c of the Act on Spatial Planning and Development (Act, 2003), placed in the road user's view, as well as any other device of visual information, together with its structural elements and fixings, other than: 
- a road sign, referred to in the regulations issued pursuant to Article 7 of the Traffic Law Act (Journal of Laws of 2012, Item 1137, as amended),

- a sign informing about the objects located by the road, including public buildings, located by the municipality,

- a sign informing about the form of protection of monuments,

- information board about the name of the form of nature conservation within the meaning of Article 115 of the Nature Conservation Act (Journal of Laws of 2013, Item 627, as amended).

\subsection{The costs incurred by the occupancy of a right-of-way for advertising}

When making a decision to place an advertisement in a right-of-way, it is necessary to remember about the need to obtain a permit from the road manager, issued by way of an administrative decision, or to sign a civil law contract. The form of a permit is specified in Article 40 Section 1 of the Act on Public Roads (Law, 1985), stating that the occupancy of a right-of-way for the purposes not related to the construction, reconstruction, repair, maintenance or protection of roads, requires a permit issued by a road manager by way of an administrative decision. This permit applies to placing ads in the right-of-way of all categories of roads. As an exception to this, within the boundaries of cities with county rights, pursuant to Art. 22 Section 2c of the Act on Public Roads, is that advertising boards and advertising devices may be located in the right-of-way under a civil law contract for pecuniary interest in cases justified by functional reasons, in particular if such boards or devices are placed on bus shelters or objects of small architecture.

The road manager charges a fee for the occupancy of a right-of-way. The fee is calculated by multiplying the number of square meters of the right-of-way occupied by the horizontal projection of a building structure or surface area of an advertisement, the number of days of the occupancy of the right-of-way, and the fee for the occupancy of $1 \mathrm{~m}^{2}$ of the right-of-way.

The rates of fees for the occupancy of the right-of-way are determined by a specific manager, depending on the road category (Table 1). A right-of-way with a surface of less than $1 \mathrm{~m}^{2}$, or a rightof-way occupied by the horizontal projection of a building structure or a device of less than $1 \mathrm{~m}^{2}$ is regarded as occupying $1 \mathrm{~m}^{2}$ of the right-of-way.

Table 1

The rates of fees for the occupancy of the right-of-way, determined by the manager

\begin{tabular}{|c|c|c|c|}
\hline Road Manager & $\begin{array}{c}\text { General Director for } \\
\text { National Roads and } \\
\text { Motorways }\end{array}$ & Local government unit & City with county rights \\
\hline $\begin{array}{l}\text { Document } \\
\text { specifying the } \\
\text { rate of the fee }\end{array}$ & $\begin{array}{l}\text { Permit issued by an } \\
\text { administrative decision }\end{array}$ & $\begin{array}{l}\text { Permit issued by an } \\
\text { administrative decision }\end{array}$ & Civil law contract \\
\hline $\begin{array}{l}\text { Maximum rates } \\
\text { for } 1 \text { day } \\
\text { occupancy of } \\
\text { the right-of- } \\
\text { way }\end{array}$ & $\begin{array}{c}\text { The fees may not exceed } \\
10 \text { PLN for one day of the } \\
\text { occupancy of the right-of- } \\
\text { way }\end{array}$ & $\begin{array}{c}\text { The fees may not exceed } \\
10 \text { PLN for one day of the } \\
\text { occupancy of the right-of- } \\
\text { way }\end{array}$ & $\begin{array}{l}\text { The value of the } \\
\text { considerations in cash or } \\
\text { in kind may not be lower } \\
\text { than the fee for the } \\
\text { occupancy of the right-of- } \\
\text { way, which would apply } \\
\text { in the case of an } \\
\text { advertising board or an } \\
\text { advertising device placed } \\
\text { subject to an } \\
\text { administrative decision. }\end{array}$ \\
\hline Current rates & $\begin{array}{l}\text { Determined in } \\
\text { accordance with the } \\
\text { Regulation of the } \\
\text { Minister of Infrastructure } \\
\text { of } 18 \text { July } 2011 \text { on the } \\
\text { rates of fees for the } \\
\text { occupancy of the right-of- }\end{array}$ & $\begin{array}{l}\text { Determined by a } \\
\text { resolution of the } \\
\text { appropriate administrative } \\
\text { body of the local } \\
\text { government unit }\end{array}$ & $\begin{array}{c}\text { Determined according to } \\
\text { the content of the civil } \\
\text { law contract }\end{array}$ \\
\hline
\end{tabular}


way of the roads

managed by the general

director of national roads

and motorways

Source: own study.

The fee for the occupancy of the right-of-way may also be increased by the amount of an advertising fee. Pursuant to art. 17a of the Act on Local Taxes and Fees (Act 1991), the municipal council may introduce an advertising fee for billboards or advertising devices. Such a fee may be imposed only in the areas for which there are terms and conditions of locating objects of small architecture, advertising boards and advertising devices, as well as fences. This fee is valid only from the date of its introduction by the municipal council. It shall be collected from the owners of the real estate or building structures, perpetual users, and the possessors of the real property on which these advertising boards or advertising devices are located, regardless of the fact whether the advertising board or advertising device displays an advertisement. Exceptions include advertising boards or advertising devices which are not visible from the space accessible to the public, signboards, or the fulfillment of the obligation imposed by the provisions of law, or solely for the purpose of disseminating information.

The amount of the paid property tax on an advertising board or advertising device shall be credited to the advertising fee due with respect to that advertising board or advertising device.

The advertising fee consists of a fixed part and a variable part. The fixed part is a flat rate irrelevant of the surface area of the billboard or advertising device for advertisement exposure. The variable part depends on the size of the surface area of the advertising board or advertising device used for advertisement exposure. If the shape of the advertising device makes it impossible to specify such area, the amount of the fee depends on the surface area of the side of a cuboid circumscribed by the advertising device.

The rate of the fixed part and the variable part of the advertising fee may not exceed the upper rates applicable to a given tax year. As of today, this is respectively 2.47 PLN and 0.20 PLN per $1 \mathrm{~m}^{2}$ of the surface area of the advertising board or the advertising device for the advertisement exposure per day, under the notice of the Minister of Finance of 24 September 2015. (Official Gazette of the Government of the Republic of Poland of 2015, Item 912). The municipal council may vary the rates of the advertising fees, taking into account the location and the size or type of the advertising board or the advertising device; it may also impose an obligation to submit a declaration regarding the advertising fee to the competent tax authority with jurisdiction over the location of advertising boards or advertising devices, as well as specify the time limit, conditions and procedure for submitting such declarations; in this case, the municipal council determines the model of the declaration form for the advertising fee, which will include data on the subject and object of taxation, necessary to assess and collect advertising fees.

It should also be remembered that the same laws that determine the rates of the fees for the occupancy of the right-of-way provide for penalties for its occupancy without a permit or a contract (Tab. 2).

Table 2

Penalties for the occupancy of the right-of-way without a permit or a civil contract

\begin{tabular}{|c|c|c|}
\hline Legal basis & Action subject to penalty & Predicted penalty \\
\hline $\begin{array}{l}\text { The Act on Public } \\
\text { Roads }\end{array}$ & $\begin{array}{l}\text { Occupancy of the right-of-way: } \\
\text { 1) without a permit issued by the } \\
\text { road manager or without a civil } \\
\text { contract in the case of cities with } \\
\text { county rights, } \\
\text { 2) beyond the term of occupancy } \\
\text { specified in the permit or in the } \\
\text { contract, } \\
\text { 3) of an area larger than that } \\
\text { specified in the permit or in the }\end{array}$ & $\begin{array}{l}\text { By way of an administrative } \\
\text { decision, the road administrator } \\
\text { imposes a fine of up to } 10 \text { times the } \\
\text { fee. }\end{array}$ \\
\hline
\end{tabular}


Occupancy of the right-of-way:

1) without a permit issued by the conditions specified in this permission

2) without the conclusion of a civil law contract for pecuniary interest, or with a breach of the terms of this contract.

\begin{tabular}{ll}
\hline The Act on Spatial & $\begin{array}{l}\text { Placing an advertising board or an } \\
\text { Planning and }\end{array}$ \\
advertising device contrary to the \\
provisions of the resolution of the \\
municipal council.
\end{tabular}
road manager or in violation of the

By way of an administrative decision, the road administrator decides about its restoration to the previous state, unless this requires the competent construction supervision authority to make a decision to demolish a building structure.

Placing a billboard or an advertising device with a breach of the provisions of the resolution of the municipal council.

\begin{abstract}
The financial penalty is imposed by
decision of the head of the
commune (mayor, city president) -
its amount is determined by
multiplying the surface area of the
billboard or the advertising device,
expressed in square meters, and 40
times the rate of the variable part of
the advertising fee adopted by the
municipal council, increased by 40
times the rate of the fixed part of the
advertising fee adopted by the
municipal council (in the absence of
a resolution - 40 times the
maximum rate of the variable part
and the fixed advertising fee,
referred to in Art. 19 clauses $1 g$ and
h (Act 1991 ), for each day of non-
compliance of the advertising board
or the advertising device with the
provisions of the resolution of the
municipal council
The obligation to adjust the
advertising board or advertising
device to the provisions of the
resolution, or removal of the board
or device under an administrative
decision of the mayor.
The financial penalty is imposed by decision of the head of the its amount is determined by multiplying the surface area of the billboard or the advertising device, expressed in square meters, and 40 times the rate of the variable part of the advertising fee adopted by the municipal council, increased by 40 times the rate of the fixed part of the advertising fee adopted by the a resolution - 40 times the maximum rate of the variable part and the fixed advertising fee, referred to in Art. 19 clauses $1 \mathrm{~g}$ and h (Act 1991), for each day of noncompliance of the advertising board provisions of the resolution of the municipal council

The obligation to adjust the advertising board or advertising device to the provisions of the resolution, or removal of the board decision of the mayor.
\end{abstract}

\section{Source: own study.}

\section{Required documentation for the occupancy of the right-of-way for advertising}

Occupancy of the right-of-way requires the submission of an application to the road manager, before the planned occupancy. This application should include (Regulation 2004):

1) the name and address, or the name and registered office of the entity applying for the occupancy of the right-of-way,

2) the purpose of the occupancy of the right-of-way,

3) the location and the surface area of the occupied right-of-way, and in the case of advertisements - the surface area of the advertisement,

4) the planned duration of the occupancy of the right-of-way.

The application must be accompanied by the following documents:

1) a detailed site plan, in a scale of 1:1000 or 1:500, with the boundaries and dimensions of the planned area of occupancy of the right-of-way, and in the case of placing an advertisement with its dimensions, 
2) an approved draft of traffic organization, if the occupancy of the right-of-way affects traffic or limits visibility on the road, or causes changes in the existing organization of vehicular or pedestrian traffic.

As seen from the above listed items, the basis for determining the area of the occupied right-of-way and the surface area of the advertisement is a detailed site plan. This requirement results in increased demand for surveying opinions aimed to determine the extent of the occupancy of the right-of-way by planned large-format advertising, but also those that give spatial information to the property manager about the conditions allowing for the placement of an advertisement only within the boundaries of the property.

Determination of the extent of the occupancy of the right-of-way by large-format advertisements placed on the facades of buildings requires the acquisition of spatial data on the geometry of the object of interest. These data may be acquired by various methods, starting with classical surveying techniques (e.g. the polar method, tacheometry), and finishing with modern techniques, such as laser scanning and close range photogrammetry.

\section{Surveying opinion performed by classical methods}

One of the tasks performed by the surveyor in connection with the planned installation of an advertisement on a building is checking whether the individual elements of the facade go beyond the cadastral boundaries of the road parcel. This is necessary because cadastral databases contain only information about the location of a basement (usually in line with the boundary of the cadastral plot), and:

- the entire facade can be tilted towards the road parcel, and therefore the advertising mesh may, especially in the higher parts, be hanging over the road parcel;

- the entire facade can be tilted towards the parcel on which the building is situated, so that the advertisement does not occupy the right-of-way;

- there might be elements on the facade which make it necessary to move the advertising mesh away from the wall, which may result in a significant trespassing the cadastral boundary and the occupancy of the right-of-way.

The process of drawing up a surveying opinion on the right-of-way occupied by a large-format advertisement using classical methods has been illustrated with two examples.

The first advertisement in the form of an advertising mesh was planned on the southern and eastern facades of a building on the corner of T. Kosciuszko Street and Z. Krasinski Avenue in Krakow. The location of the planned object relative to the boundaries between the Cadastral Parcels No. 215/2 and 395/11 (Kosciuszko Street) and 408/4 (Krasinski Avenue), Cadastral Unit No. 14 in Krowodrza District, was subject to verification. The location and facade of the building have been pictured in Fig. 1.
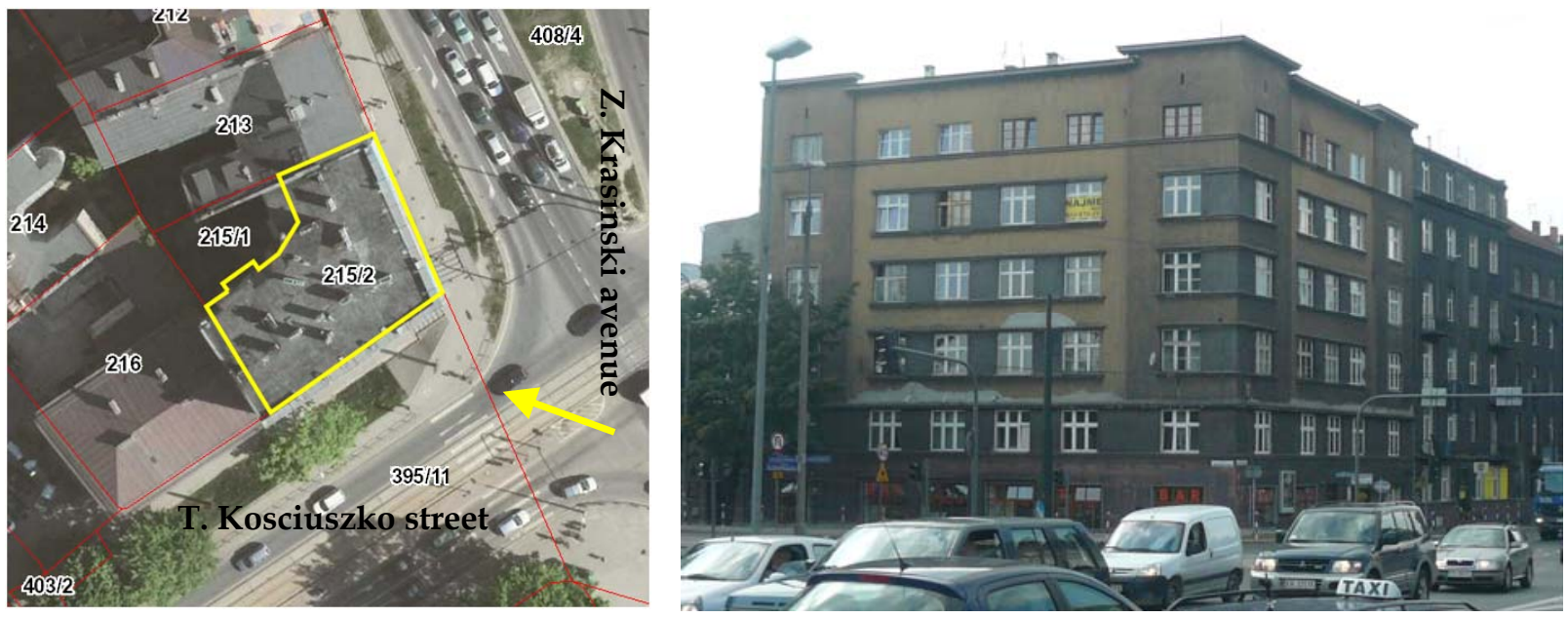

Fig. 1. Building at the intersection of T. Kosciuszko Street and Z. Krasinski Avenue in Krakow. Source: Geoportal. 
The measurement was performed with a reflectorless electronic total station, with reference to the points of the third-order national control network, the coordinates of which were obtained from the Municipal Cartographic Documentation Center database.
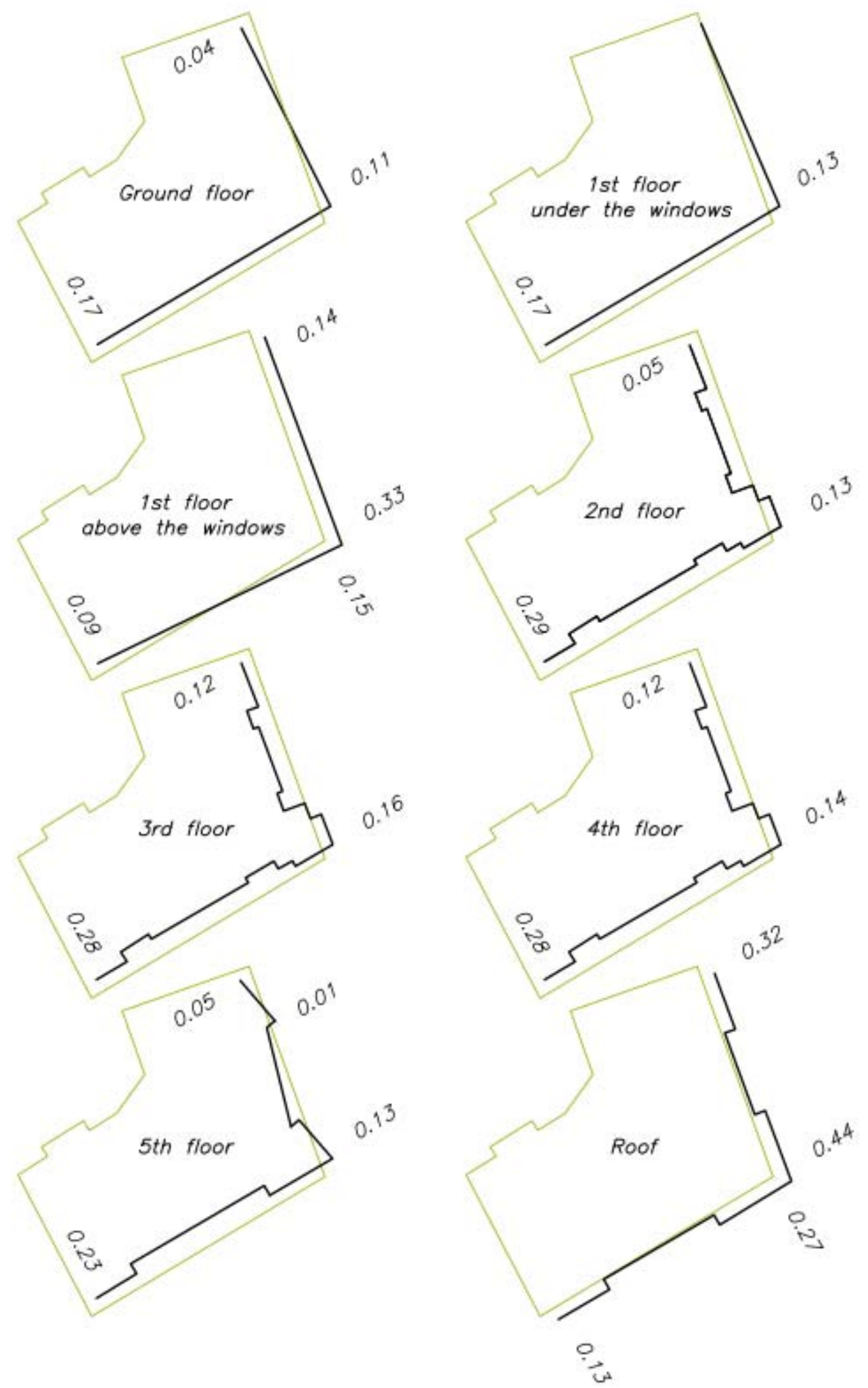

Fig. 2. Draft of the horizontal projection of the facade (black line) relative to the cadastral boundary (green line). Source: own study. 
The use of reflectorless distance measurement simplified the task significantly. There was no need to place a rangefinder mirror in the surveyed point of the facade. Specific details protruding from the walls were measured. The real property manager was particularly interested in the details located above and below the windows of the first floor. These elements protruded furthest beyond the outline of the building. Basing on the opinion prepared by the surveyor, the manager was to decide how far the planned advertising mesh would reach. Information about the location of the boundaries of the cadastral parcels needed to prepare the opinion was obtained from the Municipal Cartographic Documentation Center database. Figure 2 illustrates a comparison of the position of the elements of the facade with the cadastral parcel boundary on which the building is situated.

The second opinion concerned the advertisement planned to be placed on the east facade of the building located at the intersection of J. Slowackiego Avenue and Pradnicka Street in Krakow. The location of the planned object, relative to the boundaries between Cadastral Parcels No. 321 and 322, Cadastral Unit No. 46, Krowodrza District, and Cadastral Parcel No. 258, Cadastral Unit No. 45, Krowodrza District, was subject to verification. The location and facade of the building have been pictured in Fig. 3.
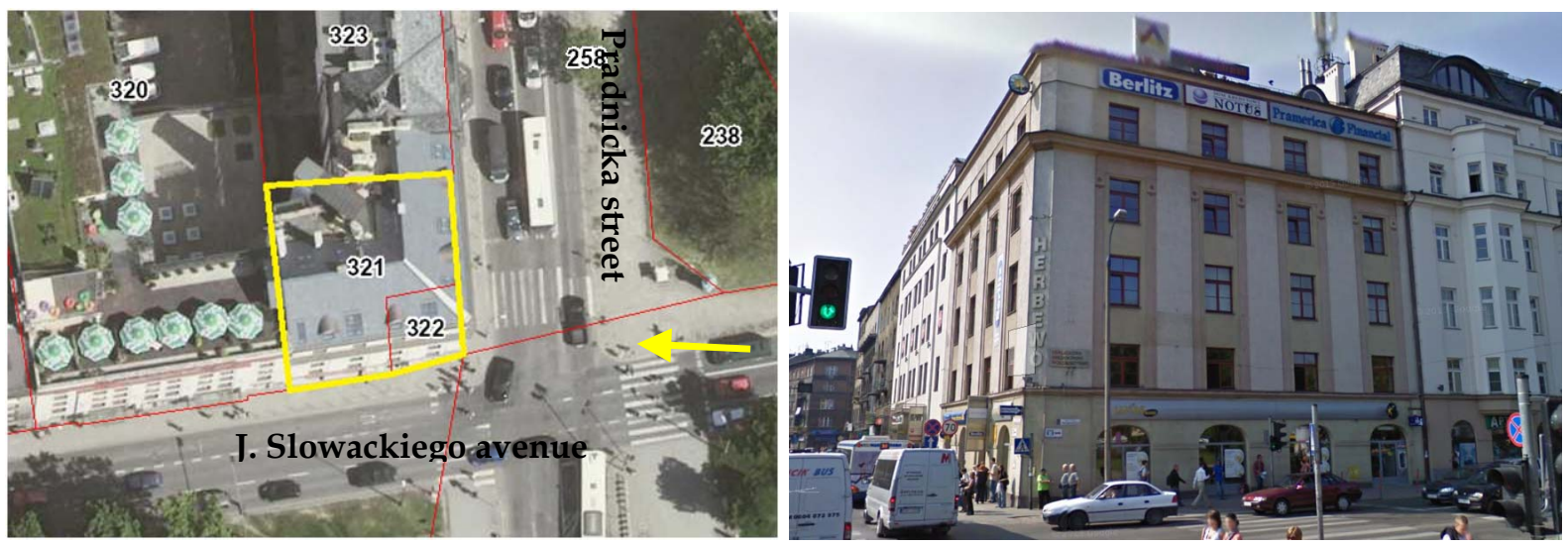

Fig. 3. The building at the intersection of J. Slowackiego Avenue and Pradnicka Street in Krakow. Source: Geoportal, Google Street View.

As before, the measurement was performed with a reflectorless electronic total station, with reference to the points of the third-order national control network. The measurement covered the characteristic elements of the facade. Figure 4 illustrates a comparison of their position with the position of the boundaries of Cadastral Parcels No. 321 and 322 on which the building is situated.

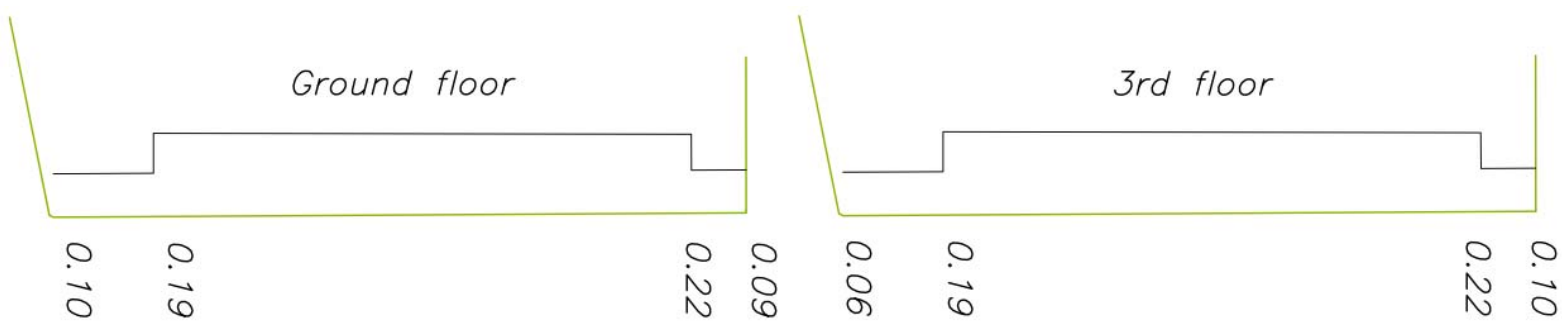

Fig. 4. Draft of the horizontal projection of the facade (black line) relative to the cadastral boundary (green line). Source: own study.

\subsection{Analysis of the obtained results}

A detailed topographic survey of the boundary markers and points, as well as of building structures, is performed in a manner which allows the position of the topographic point to be determined relative to the nearest points of the horizontal geodetic control, with an accuracy of no less than $0.10 \mathrm{~m}$ (Regulation, 2011). The presented surveys were conducted with a Trimbel M3 electronic total station, using the polar method with reflectorless distance measurement, with reference to the points of the third-order national control network. Distance measurement accuracy in the MSR mode without a mirror, according to the information from the manufacturer, is $\pm(3 \mathrm{~mm}+2 \mathrm{ppm})$. The accuracy of the angular measurement is 3 ". This means that the error of determining the position of the points on the facade, calculated from Formula (1), is approximately $3 \mathrm{~mm}$. 


$$
m_{\mathrm{pax}}=\sqrt{m_{\mathrm{L}}^{\mathrm{s}}+d^{2} \cdot m_{\mathrm{\alpha}}^{2}}
$$

where:

$d$ - the distance measured to a field detail or topographic points (up to $100 \mathrm{~m}$ ),

$\mathrm{m}_{d}$ - mean error of distance measurement $(0.003 \mathrm{~m})$,

$\mathrm{m}_{a}$ - mean error of angular measurement (3").

In both of the above cases, the project involves the installation of an advertising mesh at a distance of $7 \mathrm{~cm}$ from the facade. This means that only when the measured facade is at a distance of $7 \pm 0.3 \mathrm{~cm}$ from the plot boundary towards its center, will the mesh be installed off the right-of-way. This indicates that, in the case of the first building, the mesh suspended above the 1st floor will occupy the right-of-way only from Z. Krasinski Avenue. In the second case, the situation of an advertisement placed over the right-of-way will not occur. On the basis of the surveying opinion, property managers made decisions regarding their placement. The large-format advertisements on the above-described buildings referred to in the opinions have been presented in Figure 5.

a)

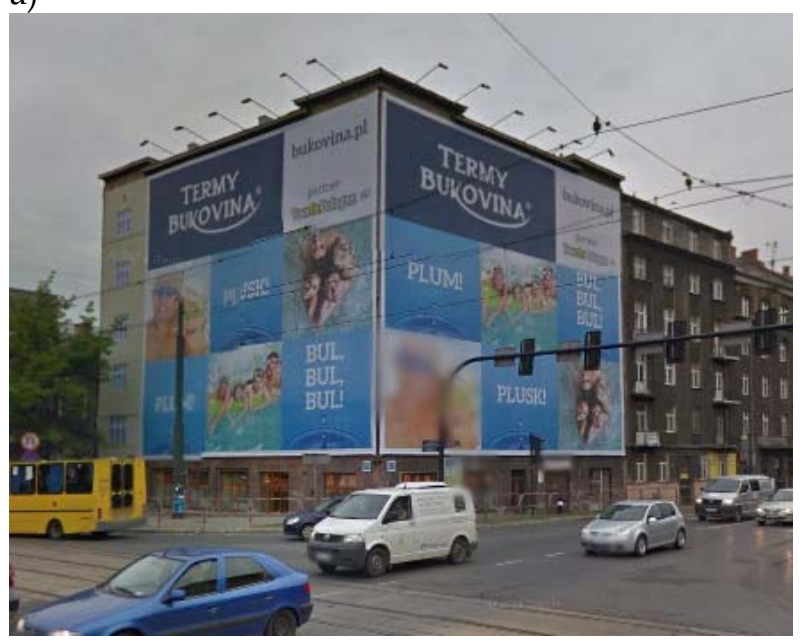

b)

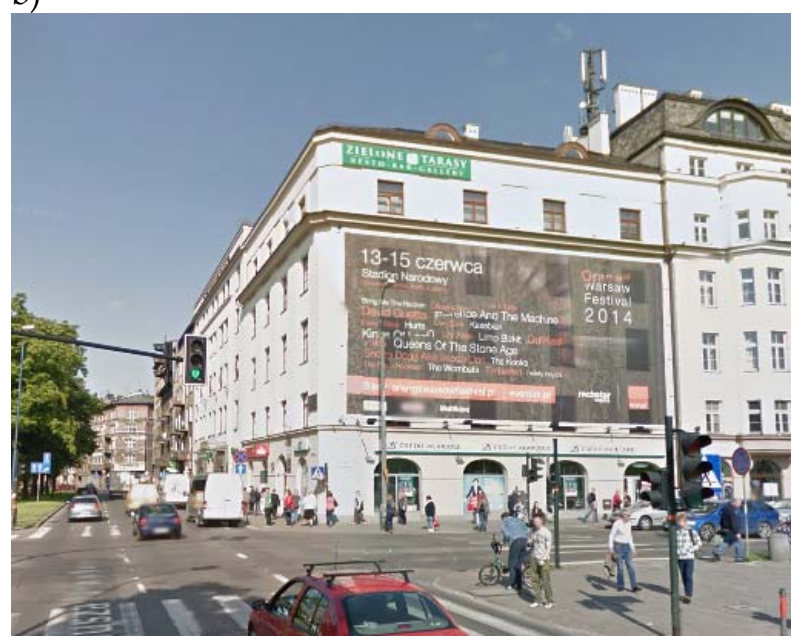

Fig. 5. Advertising meshes on buildings on: a) T. Kosciuszko Street and Z. Krasinskiego Avenue, b) J. Slowacki Avenue and Prądnicka Street. Source: Google Street View.

\section{The use of laser scanning to determine the extent of the occupancy of the right-of-way}

Laser scanning is considered to be a relatively new technique of acquiring geospatial data, even though its history dates back to the 90's of the 20th century. It is an active remote sensing system known as LIDAR (Light Detection and Ranging). The principle of operation of all laser scanners is similar and involves distance measurements of field details from the device. For this purpose, a special optical system with a specific frequency sends a measuring beam in a particular direction; the beam is reflected from an obstacle, and then received and recorded by the device. This forms the basis for calculating the coordinates of points $\mathrm{X}, \mathrm{Y}, \mathrm{Z}$ in the local system of the scanner, which can then be transformed to any geodetic coordinate system. Laser scanner imaging can be performed regardless of lighting conditions because the device usually uses radiation from the near-infrared range. Laser scanners are usually equipped with an optical sensor (built-in or external camera), through which the RGB components of each point are recorded. The product of laser scanning is a point cloud (Shan and Toth, 2008).

It is worth noting that laser scanning is a much more efficient method of spatial data acquisition than any other measurement method. It is unrivaled when measuring large spaces and complex structures, while ensuring high detail and accuracy of the measurement. Its use facilitates the fast acquisition of a point cloud of the measured object, which is a starting material for the preparation of further documentation. Laser scanning has brought about new standard of the data used, for example, for monitoring landscape (Ćwiąkała et al., 2015), records of objects and processes in the field of geomorphology and geology (Dunninga et al., 2009), architecture (Martíneza et al., 2012) or construction engineering (Park et al., 2007). 
The classical techniques of the acquisition of geospatial data, which are most commonly used for the preparation of opinions on the possibility of occupancy of the right-of-way, require property managers to have accurate information on the proposed placement of the advertising mesh. Geodetic surveys will only enable determining whether, but also to what extent, the right-of-way will be occupied by a large-format advertisement placed on the facade of a building. The situation is different in the case of using laser scanning to measure the geometry of the analyzed structure. This surveying method enables comprehensive information about the facade of the building to be acquired, making it possible to perform a variety of analyses aimed at selecting the optimal position of the planned advertising mesh.

The subject of the study included the front facades of tenement houses located on Grodzka Street in Krakow, between All Saints Square and Market Square. The scanning was performed using Leica ScanStation C10 at four stands. In order to merge the obtained data into one point cloud, a scanner control was established (Fig. 6), which was measured by the tacheometric method using Leica TCRP $1102+$. The scanning surveys were additionally tied to the two points of the third-order national control network (Kwartnik-Pruc, 2015).

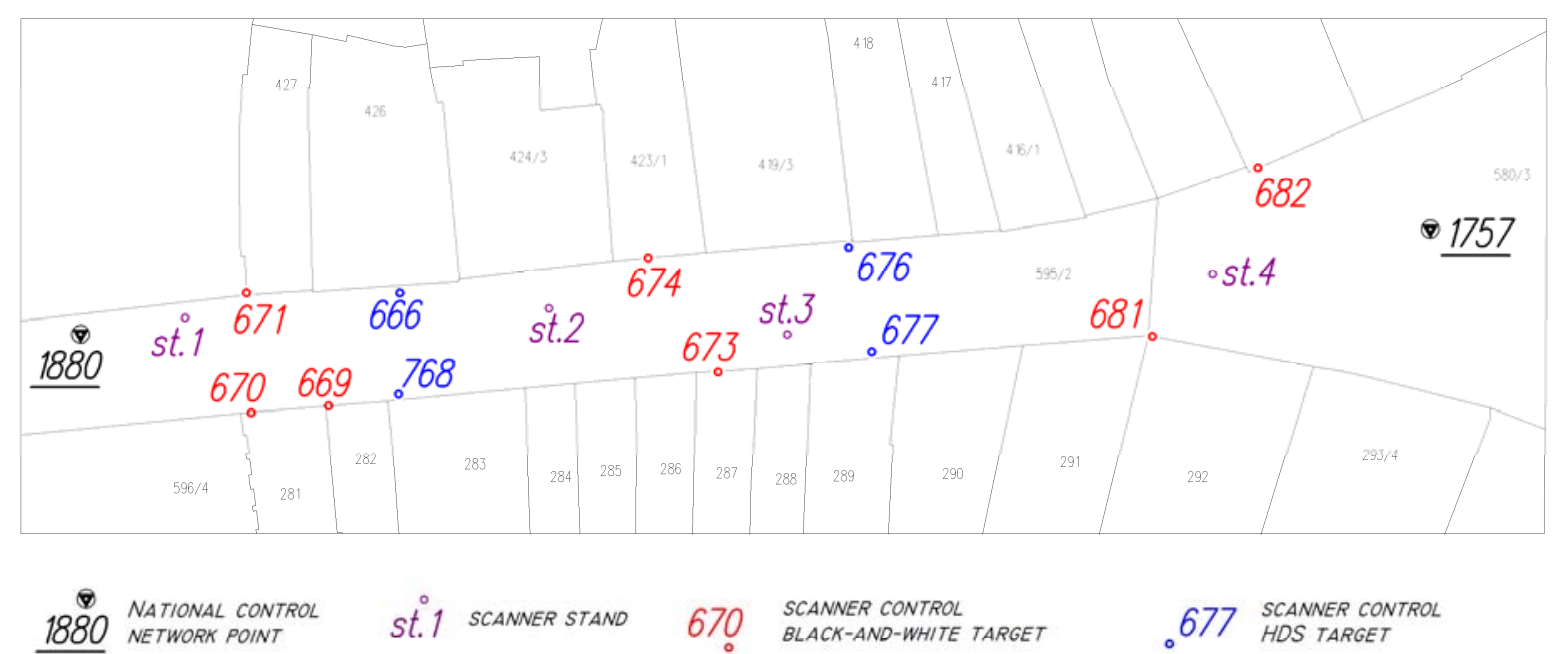

Fig. 6. Draft of the national control network. Source: own study.

Iinformation about the position of the boundaries of the cadastral parcels, which is required to prepare an opinion on the possibility of the occupancy of the right-of-way by large-format advertisements, was acquired from the Municipal Cartographic Documentation Center database.

\subsection{Analysis of the measurement results}

Analysis of the measurement results began with the determination of the coordinates of the points representing the scanner control with reference to the points of the national control network. The mean position error of the targets was 3-4 mm, relative to the points of the third-order control network. The calculated data allowed to merge data sets obtained at all scanner stands into one point cloud (Fig. 7) and to transform it to the National Spatial Reference System PL-2000. The maximum fitting error of the targets was $7 \mathrm{~mm}$. The final stage of the preliminary data preparation was filtration, during which the points which did not belong to the analyzed objects were removed. These operations were performed in Leica Cyclone software.

The main task, however, was to compare the position of the facades of the buildings (and their elements) relative to the boundaries of the cadastral parcels. The analyses were performed for several tenement houses covered by the measurement. One of them was the house at 17 Grodzka Street, located on Cadastral Parcel No. 427 (Fig. 8). The location of the structure relative to the boundary between the Cadastral Parcels No. 594/4 (All Saints Square) and 595/2 (Grodzka Street), Cadastral Unit 1, district of Śródmieście, was subject to verification. 


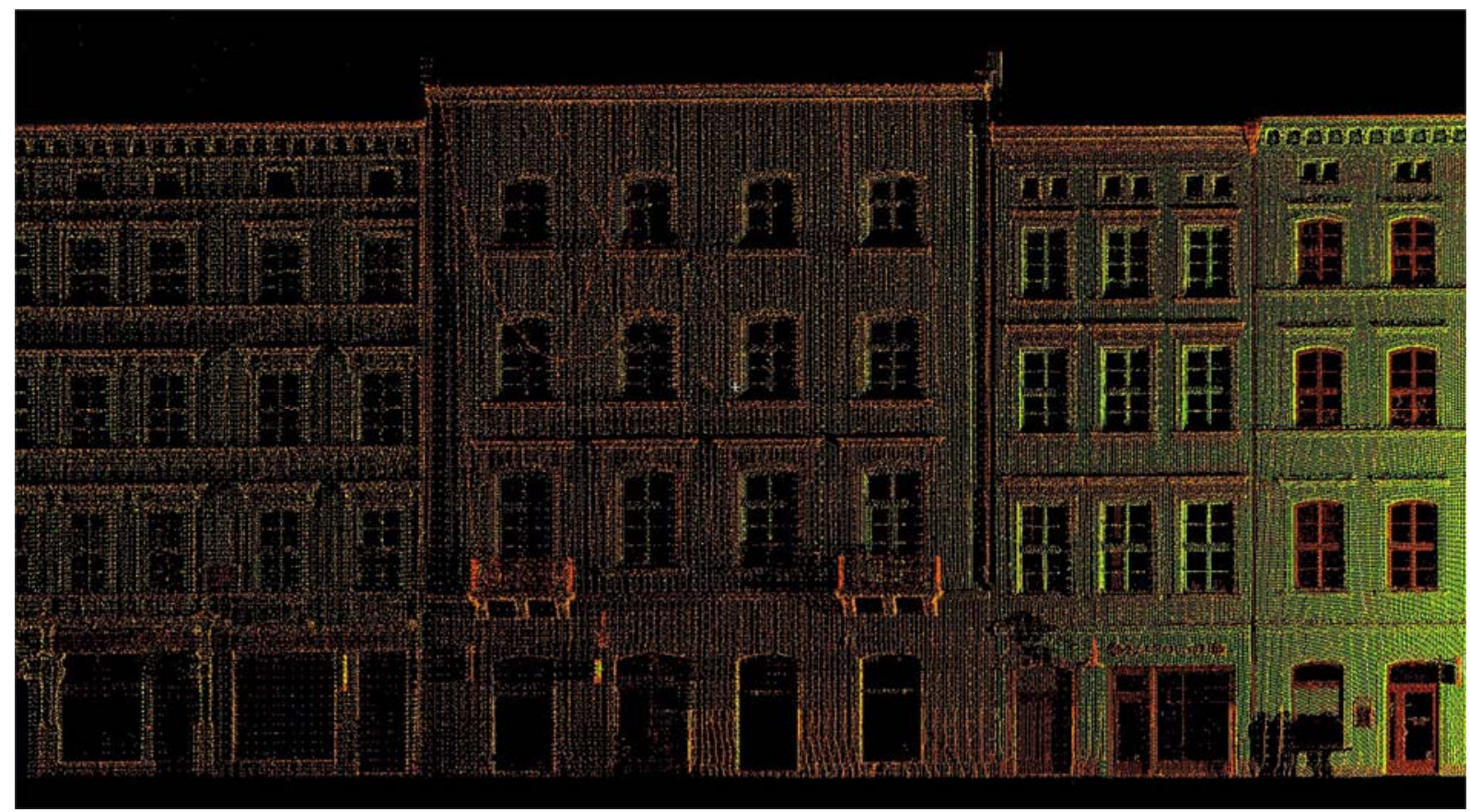

Fig. 7. Fragment of point cloud representing the analyzed structure. Source: own study.

a)

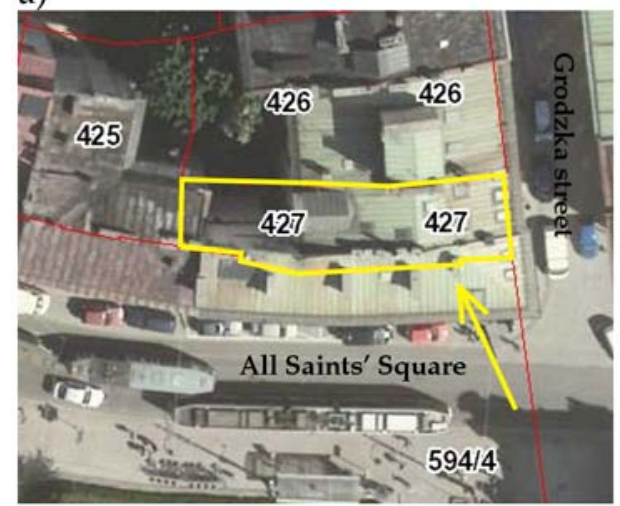

b)

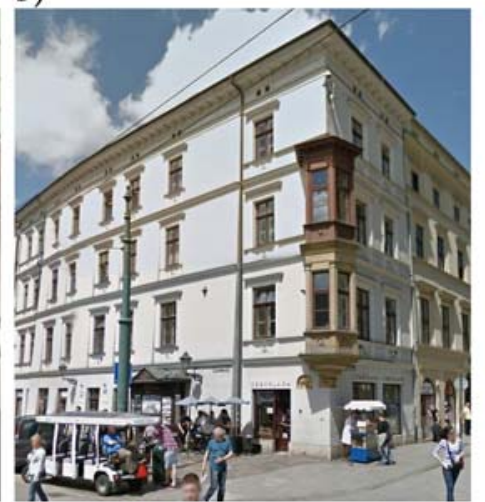

Fig. 8. Tenement house at 17 Grodzka Street in Krakow. Source: Geoportal, Google Street View.

The point cloud representing the structure (Fig. 9a) allowed quantitative and qualitative analyses aimed at selecting the right place for a large-format advertisement to be performed, and to determine the occupancy of the right-of-way for the selected location. For this purpose, the horizontal distance from the cadastral boundary was determined for each point of the cloud (Fig. 9b). These calculations were performed in CloudCompare, comparing the point cloud with the surface representing the cadastral boundary in three-dimensional space. Figure $9 \mathrm{~b}$ clearly illustrates which elements of the facade of the building overlap the right-of-way (the points marked in green and blue). It should be noted that the whole bay window on the corner of the building is located over the road parcel, similarly to the kiosk adjacent to the south facade of the building. In order to facilitate the interpretation of the scanning data with reference to a given problem, selected groups of points were excluded from the classification. Figure $9 \mathrm{c}$ demonstrates the points overlapping the right-of-way, highlighted in color. The elements located inside Cadastral Parcel No. 427 are marked in gray. Given that the advertisement mesh is always installed at a certain distance from the facade, such an analysis is not favorable from the point of view of a real estate manager. It is possible, however, to identify those parts of the facade which are located at a certain distance from the cadastral parcel boundary. Figures $9 \mathrm{~d}$ and $9 \mathrm{e}$ present the results of such analyses, with points located respectively at least $10 \mathrm{~cm}$ and $20 \mathrm{~cm}$ from the boundary in the direction of the parcel on which the building is located excluded from classification. It can be concluded, therefrom, that installing advertising mesh even at a distance of $20 \mathrm{~cm}$ from the facade of the building would not result in the occupancy of the right-of-way if the 
advertisement was placed on the south facade of the building at the height of the second and third floors.

a)

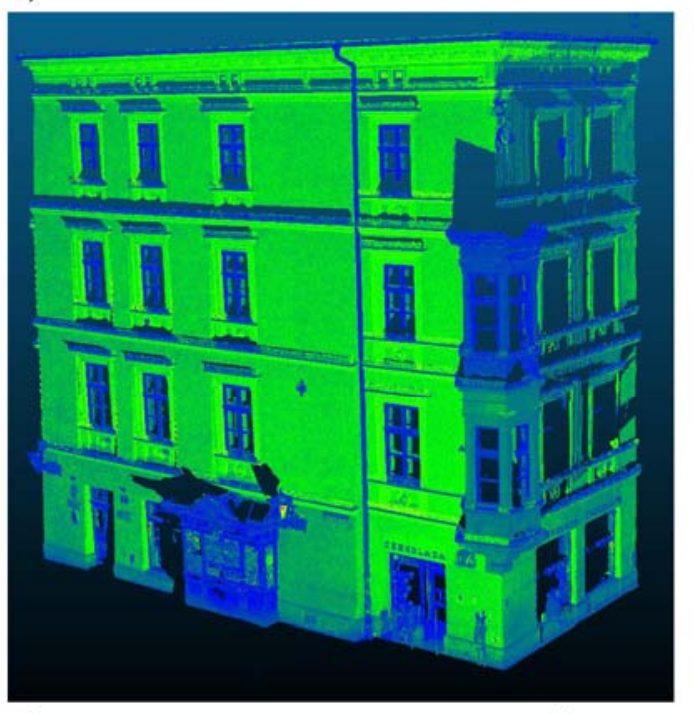

c)

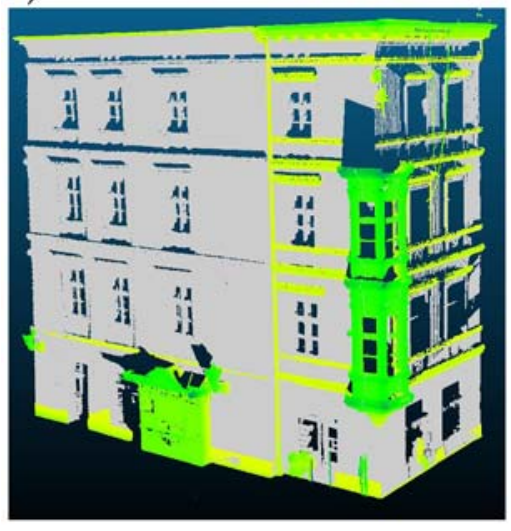

b)
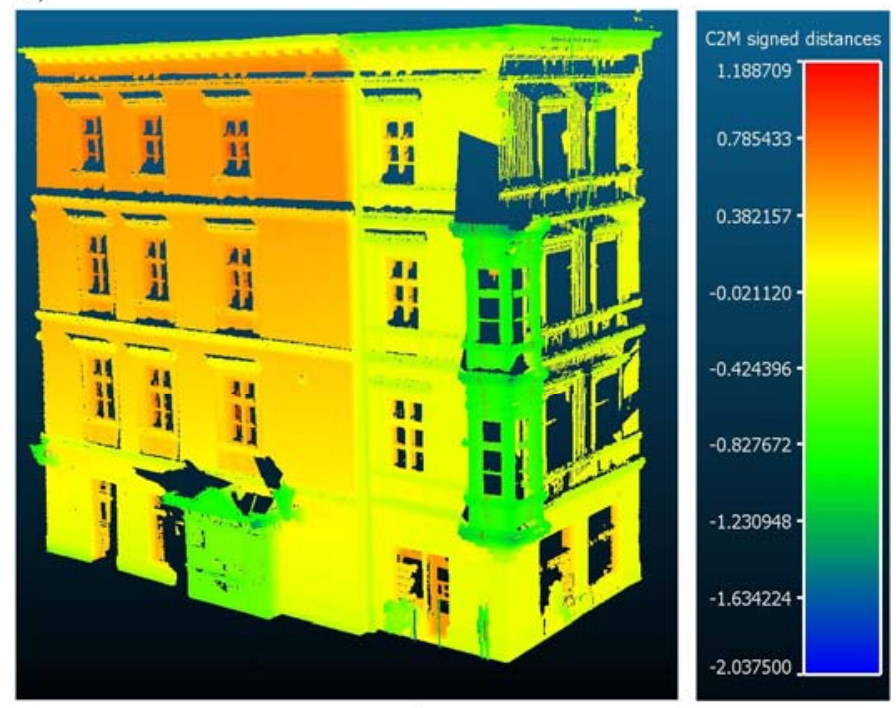

e)

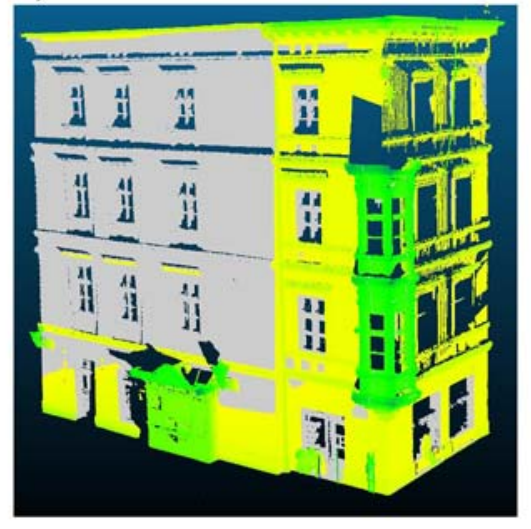

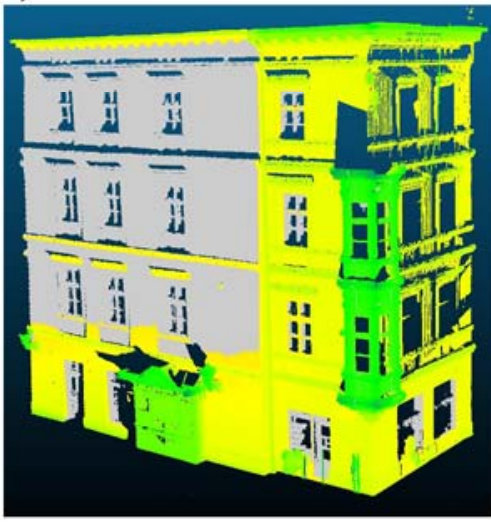

Fig. 9. Point cloud for the tenement house at 17 Grodzka Street in Krakow, and the results of the performed analyses. Source: own study.

Data from laser scanning can also be used to make cross-sections of the point cloud with horizontal planes at certain heights (Fig. 10). From the obtained sections, data sets which represent the outer surface of the facade of the building should be selected, and their position relative to the cadastral boundary should be compared. This operation makes it possible to achieve results similar to those obtained by classical surveying techniques. The advantage of scanning data, however, is their complexity, which allows any number of cross-sections to be carried out through the point cloud at selected heights. In the case of the analyzed method, there is no risk that a cross-section is not measured during field works, which turns out to be necessary at the stage of data analysis.

Similar analyses were also performed for the building at 3 Grodzka Street, located on Parcel No. 416/1. The location of the building relative to the boundary with Cadastral Parcel No. 595/2 (Grodzka Street), Cadastral Unit 1, Śródmieście District, was subject to verification.

First, the horizontal distances of the points representing the front elevation of the building from the boundary were established (Fig. 11a). The comparison made it possible to notice that the ground floor of the building was not consistent with the boundary of the cadastral parcel, and the whole facade is tilted towards the parcel on which the building is located. Figure 11c demonstrates the points which belong to the right-of-way (the distance between these points and the boundary is $0 \mathrm{~cm}$ or more); Figure $11 \mathrm{~b}$, on the other hand, illustrates the points overlapping the right-of-way by as much as $10 \mathrm{~cm}$ or more, highlighted in color.

The next step involved an attempt to select the optimum place where it would be possible to install an advertising mesh without the risk of occupying the right-of-way. For this purpose, it was checked 
which parts of the facade of the building were located at a minimum distance of $10 \mathrm{~cm}$ (Fig. 11d) and $20 \mathrm{~cm}$ (Fig. 11e) from the boundary, in the direction of the parcel on which the building was located. The elements highlighted in gray in Figures $11 \mathrm{~d}$ and $11 \mathrm{e}$ are the areas where the advertisement, if placed at a distance of $10 \mathrm{~cm}$ (Fig. 11d) or $20 \mathrm{~cm}$ (Fig. 11e) from the facade of the building, would not occupy the right-of-way. It is clear that there are only a few such areas. Therefore, the decision to install a large-format advertisement on this tenement house will result in the occupancy of the rightof-way and the need to incur relevant duty charges.
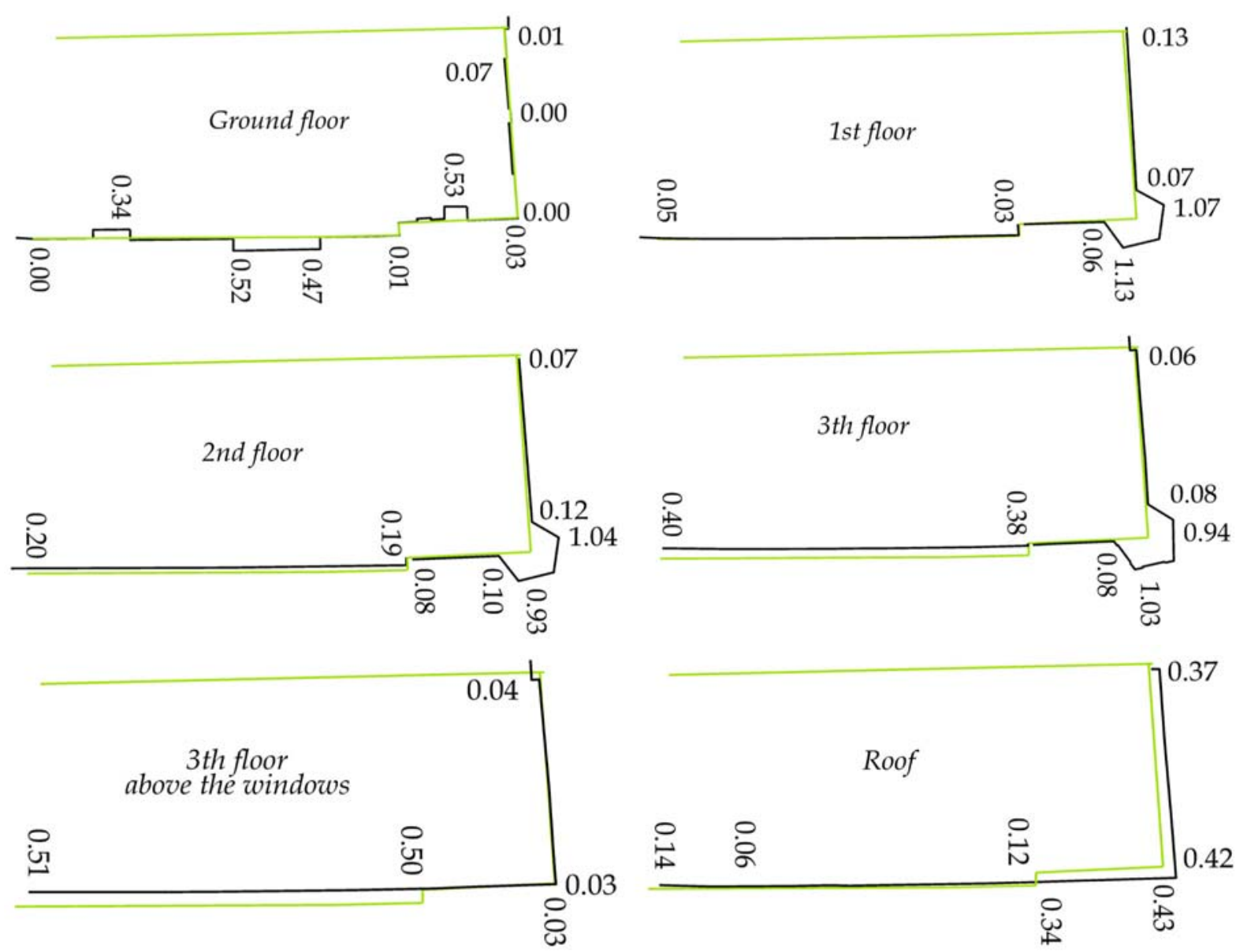

Fig. 10. Draft of the horizontal projection of the facade (black line) relative to the cadastral boundary (green line). Source: own study.

a)

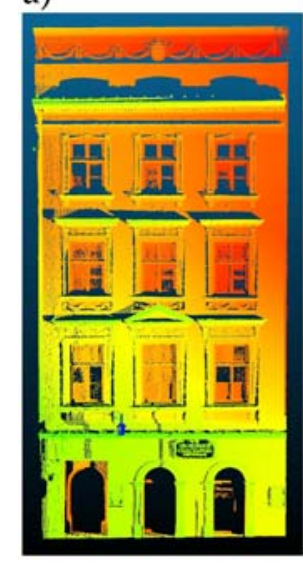

b)

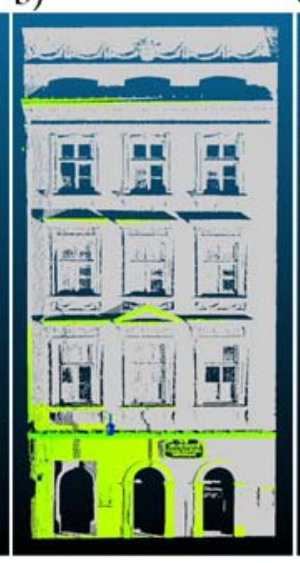

c)

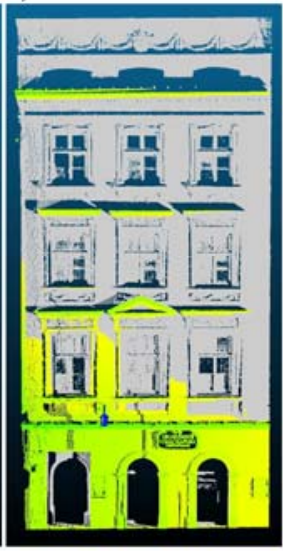

d)

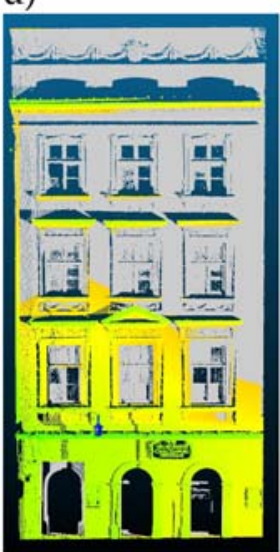

e)

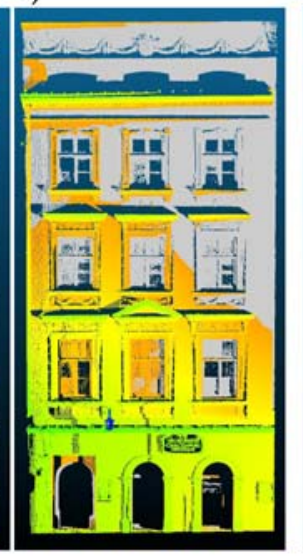

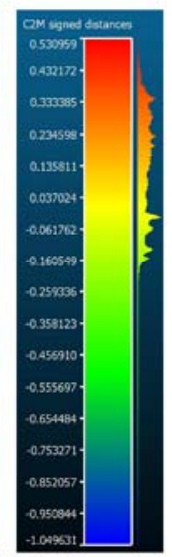

Fig. 11. Point cloud for the building at 3 Grodzka Street in Krakow and the results of the performed analyses. Source: own study. 
Similar studies can be performed for each building whose facades were surveyed using laser scanning. It should also be noted that laser scanners are often used for architectural surveys of facades. The point cloud acquired for this purpose may also be used in the future by property managers to analyze the possibilities of occupying a right-of-way by advertisements planned on the facade.

Finally, it should be noted that imaging the surroundings of the right-of-way by laser scanning can also be used by public road managers to determine the illegal occupancy of the right-of-way by various parts of the facades of buildings (e.g. balconies) (Fig. 12b) or elements installed on them (e.g. advertising signboards) (Fig. 12a). For the occupancy of the right-of-way without a permit, the road manager should impose a penalty by way of an administrative decision.

a)

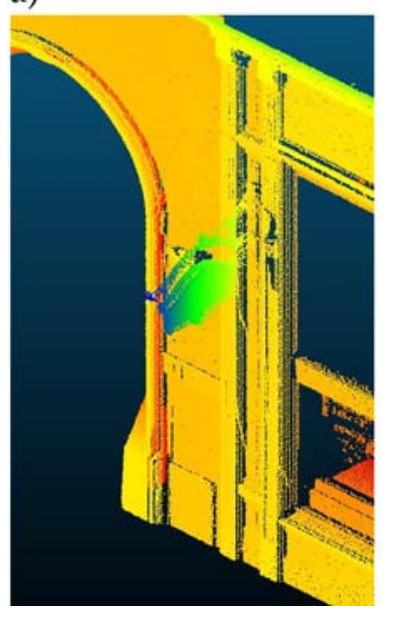

b)

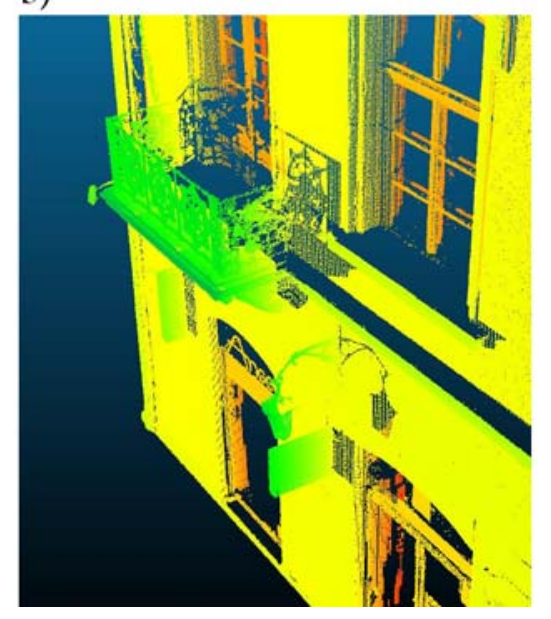

Fig. 12. Examples of elements occupying the right-of-way. Source: own study.

\section{Conclusions}

The surveying opinion related to the intended use of the facade of a building to install a large-format advertisement allows for acquiring spatial information necessary for the property manager to make a conscious decision about the implementation or abandonment of such an investment. If the decision is positive, the manager has the possibility of choosing the most optimal structure of the planned advertisement so as to avoid or minimize the fees for the occupancy of the right-of-way.

The use of both classical and modern surveying techniques provides an answer regarding the extent of the occupancy of the right-of-way. However, the use of a modern surveying method, such as laser scanning, allows numerous additional data that can be used to perform detailed spatial analyses to be acquired.

The prepared opinion consists of the site plan including a graphical representation of the range of property boundaries and the elements of the facade of a building which may be of interest to the property manager. The plan, supplemented with the dimensions of the planned occupancy of the right-of-way and the dimensions of the advertisement, can be a required attachment to the application for a permit to occupy the right-of-way. There is no need to commission the preparation of a separate document.

The study has been carried out with the financial support of Statutory Research No. 11.11.150.005 and 11.11.150.006 of AGH University of Science and Technology.

\section{References}

BIEDA, A., HANUS, P., 2010, Determination of Real Estate Boundaries for the Purposes of Subdivision Process. Geomatics and environmental engineering, Vol. 4 No. 1, pp. 15-20.

ĆWIĄKAŁA P., PUNIACH E., JAROSZ M., KMAK K., 2015, The Surveying Inventory of Kraków-Częstochowa Upland's Rocks Illustrated with the Example of the Hercules' Club (Maczuga Herkulesa) in Pieskowa Skata, Geomatics and Environmental Engineering, Vol. 9, No. 1, pp. 15-23. 
DunNinga S.A., MASSEYB C.I., ROSSER N.J., 2009, Structural and Geomorphological Features of Landslides in the Bhutan Himalaya Derived from Terrestrial Laser Scanning, Geomorphology, Vol. 103, pp. 17-29.

KWARTNIK-PRUC A., 2015, Possibilities of Using Innovative Sources of Information on Real Estate in the Spatial Data Collection Process, Real Estate Management and Valuation, Vol. 23, pp. 103-113.

LICHTENTHAL, J. D., YADAVA V., DONTHUB N., 2006, Outdoor Advertising for Business Markets, Industrial Marketing Management, Vol. 35, pp. 236-247.

Martíneza J., Soria-Medinab A., Ariasa P., Buffara-Antunes A.F., 2012, Automatic Processing of Terrestrial Laser Scanning Data of Building Façades, Automation in Construction, Vol. 22, pp. 298-305.

PARK H. S., LeE H. M., Adeli H., LeE I., 2007, A New Approach for Health Monitoring of Structures: Terrestrial Laser Scanning, Computer-Aided Civil and Infrastructure Engineering, Vol. 22, pp. 19-30.

PŁUCIENNIK M., HeŁDAK M., WeRner E., 2015, Fees for Advertisements in the Right-of-Ways of Public Roads Incurred by a Given Bank Brand in Poland, Real Estate Management and Valuation, Vol. 23, No. 4, pp. 52-61.

ROZPORZĄDZENIE Ministra Spraw Wewnętrznych i Administracji z dnia 9 listopada 2011 r. w sprawie standardów technicznych wykonywania geodezyjnych pomiarów sytuacyjnych $i$ wysokościowych oraz opracowywania $i$ przekazywania wyników tych pomiarów do państwowego zasobu geodezyjnego $i$ kartograficznego (Regulation of the Minister of Internal Affairs and Administration of 9 November 2011 on the technical standards for the performance of geodetic topographic and detailed measurements as well as the preparation and transfer of these measurements to the National Cartographic Documentation Center database) (JournAl of LAWS No. 263, Item 1572).

ROZPORZĄDZENIE Rady Ministrów z dnia 1 czerwca 2004 r. w sprawie określenia warunków udzielania zezwoleń na zajęcie pasa drogowego (Regulation of the Minister of Internal Affairs and Administration of 9 November 2011 on the technical standards for the performance of geodetic topographic and detailed measurements as well as the preparation and transfer of these measurements to the National Cartographic Documentation Center database) (JOURNAL OF LAWS No. 263, Item 1572).

SHAN J., Tотн C.K., 2008, Topographic Laser Ranging and Scanning: Principles and Processing, CRC Press.

UstaWA z dnia 21 marca 1985 r. o drogach publicznych (The Act of 21 March 1985 on Public Roads) (JOURNAL OF LAWS of 2015, Item 460, as amended)

USTAWA z dnia 12 stycznia 1991 r. o podatkach i optatach lokalnych (The Act of 12 January 1991 on taxes and local fees) (JOURNAL OF LAWS of 2014, Item 849, as amended)

USTAWA z dnia 24 kwietnia 2015 r. o zmianie niektórych ustaw w związku ze wzmocnieniem narzędzi ochrony krajobrazu (The Act of 24 April 2015 on amendments to some laws in connection with the strengthening of the tools of landscape protection) (JOURNAL OF LAWS of 2015, Item 774)

USTAWA z dnia 27 marca 2003 r. o planowaniu i zagospodarowaniu przestrzennym (The Act of 27 March 2003 on Planning and Spatial Development (JOURNAL OF LAWS of 2015, Item 199, as amended)

Geoportal, http://www.geoportal.gov.pl, accessed: 15.01.2016.

Google Street View, https://www.google.pl/intl/pl/maps/streetview, accessed: 15.01.2016. 